\title{
Exploration of Entrepreneur's Challenges to Cope with Nepalese Tourism Market Dynamics
}

\author{
${ }^{1}$ Bal Ram Bhattarai*, ${ }^{2}$ Manoch Prompanyo

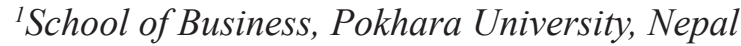 \\ ${ }^{2}$ Shinawatra University, Thailand \\ *Corresponding author: bhattaraibr6@gmail.com
}

\begin{tabular}{l} 
Article History \\
Received 11 April $2021 \quad$ Revised 12 November $2021 \quad$ Accepted 21 November 2021 \\
\hline
\end{tabular}

\begin{abstract}
Change is inevitable in every sphere of human life; tourism activities are rapidly changing than other activities. The Nepalese tourism industry has also brought changes in different aspects, how those changes are perceived by the entrepreneurs of the industry is the main concern of the study. The primary objective of this study is to explore the dimensions of tourism market dynamics and entrepreneur's readiness to cope with the perceived challenges. A qualitative framework has been adopted of an in-depth interview with leading entrepreneurial personalities of the tourism industry of Nepal. Representing hospitality, catering, trekking, and travel with at least 20 years of experience in tourism-related activities are considered as the true representation to collect primary data. Manual thematic content analysis has been employed to generate the theme of the interview. Major changes in customer expectation because of the market shift, technological advancement but not appropriate application, lacking experienced trained human resources, and travel-related inconvenience are the major challenges for tourism entrepreneurs of Nepal.
\end{abstract}

Keywords: Nepal, tourism, tourism entrepreneur, market dynamics, service quality

\section{INTRODUCTION}

Tourism entrepreneurs are planning to face market dynamics in the Nepalese tourism market and service providers are developing and responding to the changing market pattern.

(C) The Author, published by JRCC, Janapriya Multiple Campus. 
Change is inevitable in every walk of life; like that tourism is one of the retrospectives in modern days. Like another market, the tourism market has a huge effect from socio-political, legal, economic and, other broader environmental aspects. The technological change has brought a structural change into the market. Other problems created from different diseases like COVID-19 also brought an unpredicted landscape of the market. Khanal (2020) has mentioned that the impact of COVID-19 will remain at least two more years to keep the tourism survive, there is a need of promoting domestic tourism but the second and third web of corona-virus has created a daunting pressure on the survival of the tourism industry of Nepal.

Considering the broader environment of the market as the technological, economic, socio-cultural, and political environment of the world entrepreneurs need to be prepared to go with it. Technological advancement is far away and giving more pressure on going together with the rest of the world if one wants to serve international visitors (Bakas et.al., 2019). The information received from Digital media is more prompt, accurate, and sufficient than that of traditional sources of information to which service providers have to have close monitoring, understandings, and adjusting (Binkhorst \& Den Dekker, 2009). The use of information communication technology in the tourism industry can significantly enhance the competitive position of the industry particularly small and medium-sized tourism service providers (Buhalis \& Deimezi, 2004). Technological changes are inevitable but destination marketing organizations are found reluctant to accept and adopt technological change (Gretzel et al., 2006).

Since most of the destinations face seasonal fluctuation of the visitors. Managing human resources at the destination is another crucial issue. Sometimes there is labor overflow while on the other time there will be a labor shortage which also equally affects the rewarding and compensating the workforce. Training, educating, and developing the workforce to make committed to effective quality tourism service delivery is also challenging the tourism entrepreneurs. Customer satisfaction is an abstract and complicated phenomenon. Since satisfaction highly depends upon the visitor's expectation, perception and, emotional experience, attitude and leadership qualities have been found as the primary success factors for the tourism entrepreneurs of the day but the new entrants of the tourism sectors especially in hospitality are very little prior experience (Zeithmal, Bitner \& Gremler, 2006). While Power, Di Domenico and Miller (2017) urged that attributes of tourism entrepreneurs are traditional, egoistic, opportunity seeking and risk-taking for better profitability rather than long-term customer relation and quality enhancement. 
Commonly available works of literature in the field of tourism study are based on the developed world "it is not fair that the culture and other historical shreds of evidence might have to differ on the basis of social settings" (Tribe, Xiao \& Chembers, 2012). Identifying customers' expectations is the main concern for every entrepreneur for their business success. There is a need for developing activities and programs as per the customer's perception and expectations as per the changing situation. Marketing of services always pays due attention to the customers' expectations and satisfaction may be shaped the visitor's personality and the general environmental factors (McCollough, Berry \& Yadav, 2000). Tourism knowledge is contingent and based on people who can talk more to convince about the subject matter have the domination on it. Thus tourism researches cannot be restricted to a particular paradigm. Tourism research should explore the prominent truth which may be peculiar to each destination and cultural setting (Tribe, 2006).

The philosophical understanding of service quality is in the tourism sector based on matching the expected needs of the visitors with respect to the perceived experience at the destination. As a qualitative approach of the study, where semi-structured in-depth interviews are the main source of the data collection, grounded theory should have prevailed. Constant comparison and sensitizing the responses are the prime concern in such studies (Glaser Strauss, 2009; Tribe_Xiao \& Chembers, 2012; Zhang, 2018). Rationalism is the primary basis for justifying believes and claims of the interviewees. Multiple realities have been accepted rather than a single truth of the particular phenomenon. The qualitative interviews are not limited to a particular theory nor are these interviews sufficient for theoretical justification (Charmaz, 2008; Mura \& Khoo-Lattimore, 2018).

There are a number of studies in the Nepalese tourism industry. Almost all are about sustainability and other economic perspectives; researches regarding marketing particularly about changing market situation are not available (Lu \& Nepal, 2009; Pandey et al, 1995; Bist, 2009; Sharma, 2012). Whilst, such studies are very common in the rest of the world, no matter developed or least developed particularly tourism-focused nations (Novelli, Morgan, \&Nibigira, 2012; Gretzel et al., 2006; Castro \& Ferreira, 2019; Lin, Lin \& Chen, 2017; Jaafar et al., 2011; Sharma, 2013). A question may raise that about exploring the tourism entrepreneur's preparedness to deal with the changing market situation and how the tourism entrepreneurs have made themselves go forward according to the changing environment. This study is an attempt to explore the dimensions of tourism market dynamics and entrepreneurs' readiness to cope with the perceived challenges. 
Tourism can accelerate the economy of a fragile nation at a greater speed. It can act as the panacea for such nations. The post-conflict situation in the least developed countries lacks human resources as per the market need. Expectations and aspirations of people are unrealistic. Strategy implementation problems and the benefits of tourism can go to limited hands. Fragility is searching for state functioning in an ideal way. Fragility cannot neatly map it is the only relation with the resilience country. Social expectation and capacity delivery with respect to authority, legitimacy, and stability are the fundamentals of the fragility of the nation (Novelli, Morgan \& Nibigira, 2012).

Gretzel et al., (2006) in their qualitative exploratory research found that resources are not sufficient and compatible to deal with change, problems on appropriately identifying customer's needs, destination marketing activities are also associated with destination management activities, customer satisfaction should be the prime focus no matter profitseeking or not for profit organization, the partnership of different levels determine the success of tourism organization and every organization has to cope with the changes that have taken place in technology as well as customer preference.

Entrepreneurs' self-perception of tourism skills and competencies determine the success of rural tourism. Personal maturity factors as emotional coping, ability to think critically, and networking as the underlying competencies for rural micro and small tourism entrepreneurship. Education of the tourism entrepreneurs' attitude and explore opportunities while past experience encourages managing the enterprise (Shaw, 2014). Micro and small tourism entrepreneurs of northern Portugal lack the marketing and management skills of rural tourism activities (Castro \& Ferreira, 2019).

Customer services are the most entrepreneurial competency followed by the skills and attitude of a tourism entrepreneur of farm tourism for the balanced development and up-gradation of tourism. New skills and competencies are always important for remaining competent in business. The others are aware of their own competency, business-specific competencies, and learning attitude and skills developments according to the nature of tourism entrepreneurship (Phelan \& Sharpley, 2012).

Lin, Lin, and Chen (2017) have developed a conceptual framework on the study of professional competency of tour guide that professional skills are the most important dimensions for professional competencies followed by professional attitude and knowledge. Tour guides' service qualities highly influence visitors' satisfaction. Tour guide service quality was found the most critical dimension for the overall tourism service quality of a destination. A 
tour guide must understand tourist expectations with a positive service attitude and efficiency.

Malaysian research referencing the issues of developing countries in a mixed-method study argues that Self-confidence, independence, and the ability to learn from failure are the most important entrepreneurial characteristics for success in the tourism business in Malaysia. Familiar and up-date information technology is a must in the tourism business. Most Malaysian tourism entrepreneurs are facing the problem of knowledge and skills of operating accommodation facilities (Jaafar et al., 2011).

A case study method of adjacent tourism entrepreneurs of three national parks in Finland had conducted an investigation of the exploitation of the business opportunity. Hotel, catering services, transport agents, tourism-related product selling kiosks, and grocery store owner's surveys depict that entrepreneurial success in tourism is primarily based on human capital development. Adaptive entrepreneurs are more successful than innovative entrepreneurs. Parental entrepreneurial practice can positively contribute to the children entering into the tourism entrepreneurial business. The attitude of the entrepreneurs does not necessarily lead to commitment in the tourism industry in Finis tourism entrepreneurs (Selby, Petajsto, \& Huhtala, 2011). Alina and Daniel (2014) in their study lifestyle of European tourism entrepreneurs said that long experience in the tourism sector and leisure orientation are the main motivators to enter into tourism entrepreneurship in Europe rather than the profit motive.

The review of the extant empirical literature on entrepreneurs' success factors in tourism reveals that studies in the area in the case of the tourism industry are scanty. Moreover, the studies carried out in the context of developing and underdeveloped economies are very few. Prior studies are focused on the general aspects like socioeconomic impact, ecotourism, sustainable tourism, and other such studies (Lu \& Nepal, 2009; Pandey et al, 1995; Bist, 2009; Sharma, 2012) and more other tourism-related studies of Nepal are not related to the market and entrepreneur's aspects of tourism. Tourism researches are concentrated in European and developed countries. Thus, there is a domination of Eurocentric knowledge in tourism knowledge creation particularly marketing and entrepreneurial aspects of tourism (Tribe, Xiao \& Chembers, 2012). From this juncture, we can urge that customers' expectations and responses are changing; entrepreneurs may not precisely be able to carry out their activities as per the market dynamics. Moreover, the studies carried out in the context of underdeveloped economies are very less especially tourism entrepreneurship coping with market dynamics. 


\section{DATA AND METHODS}

A qualitative framework has been adopted to conduct the study. From the review of the literature that different studies for a preliminary exploration of the entrepreneurs' planning on the adaptation of the changed situation, qualitative particularly in-depth studies (Gretzel et al., 2006; Chan, et al, 2016; Blodgett, et al., 2009; Bosworth \& Farrell, 2011) have adapted to conduct their research work and this study also had been carried out an in-depth interview of tourism entrepreneurs and experts to explore how they are prepared to cope with the market dynamics. Qualitative researches are a fundamental foundation for contributing global knowledge above quantitative research. Non-western ontologisms and epistemologies can be a paradigm shift of the Asian research on western positivism (Mura \& Khoo-Lattimore, 2018; Zhang, 2018). Different techniques can be adopted for analyzing qualitative data like critical discourse analysis, narrative analysis; thematic content analysis, and analyzed using grounded theory (Tribe, Xiao \& Chembers, 2012). Statistical techniques are appropriate when there is identified magnitude of the problem. Qualitative data are important to identify the reason and understand the process. Thus, qualitative methods are appropriate for a deeper understanding of the subject matter especially in consumer behavior and services marketing (Granot, Brashear \& Motta, 2012). Data related to the behavioral type and value-laden by the group of people need to have an exploratory type investigation (Creswell et al, 2003). As a behavioral study, it has been understood that the philosophical assumptions as multiple realities and subjective evaluation of the phenomena. Subjectivity may exist in the understanding of the activities by the respondents (Marshall \& Rossman, 1999). Due consideration has been given for minimizing the subjectivity while gathering and interpreting the information.

An audio recording system has been used to record all the interviews. A checklist was developed to conduct interviews with entrepreneurs. Questions were open-ended, starting from the general situation of the tourism business in Pokhara, Nepal. The interactive and cumulative nature of the questions should be adopted keeping the interview subject matter focused, the interviewer must be open and balanced while conducting an in-depth interview (Granot, Brashear \& Motta, 2012). Though there was some adjustment as per the discussion has gone with the interviewee, the questions were similar type almost all of the respondents (appendices). The sequence was as: the visiting trend of the tourist from different parts of the world and flowed by general infrastructures related activities for tourism developments. After that, the questions were asked relating to the quality of services and customers' complaints about how they are prepared to mitigate the challenge of technological advancement, customer 
preference, and different environmental forces. Though there are questions in the checklist in English, all questions were asked primarily in the Nepali language with all respondents of entrepreneurs. The interviews had held in December 2018.

All of the respondents were previously informed on recording the interview in an audio recorder, the recording is made only after approval from the interviewee. The name and contact number of concerned entrepreneurs were obtained from the Nepal Tourism Board Pokhara office. Since almost all the interviews were recorded in an audio recording system. First of all the transcripts of the interviews were made in English which are kept safely. Content analysis was made to analyze the interview transcripts. Analyses were made manually; there is no support of computer software on processing the data. Through and a very careful reading of the transcript was made to get the main theme of the interviewees with a prolonged note on it. Transcripts verification was also made with two of the interviewees to assure the reflection of the transcript with their interview. Labeling activities were also made to identify the relevant words, phrases, and sentences, repeated in several places. Due attention has been given to analyzing the interview transcript to maintain and reflect the theme of the interviewee. Translation of the interview from the Nepali language to English was made very carefully, on selecting appropriate words or phrases that more precisely represent the idea of the interview. To minimize the biases much consideration was given to objects and other different activities associated with processing the interview. The researcher had paid due attention to keep him from the research. The categorization of the analysis was made on the general understanding of the nature of the idea expressed by the interviewees. Granot, Brashear and Motta, (2012) suggest that when participants' comments are placed as they are in the report boost the validity and prove the internal consistency of the data.

\section{RESULTS AND DISCUSSION}

World tourism has been fundamentally changed in its traditional status. Primarily the changes are in technology, visitors' nature, and expectations, competitive positions, and the broader environmental forces. It is necessary for the tourism entrepreneurs to make a continuous up-gradation and adjustment of their offering as change has taken place in customers. Changes in customer expectations can have a huge impact on the overall tourism industry. It is important to consider global environmental changes to serve foreign visitors (Gretzel et al, 2006). Tourism entrepreneurs must step forward to make compatible with the changed situation. Major following seven challenges have been identified to the Nepalese 
tourism entrepreneurs to make them compatible with the global tourism market.

\section{Change in Customer Expectations}

The history of tourism in Nepal particularly in Pokhara starts from backpackers while nowadays service providers have to deal with conference and corporate tourism; types of visitors are also changing. Entrepreneurs of tourism must diversify tourism activities as per the nature of tourists; there is a need for further diversification for a better number and better quality of tourism services (R4 and 5). In the initial days, tourists used to come for adventure and trekking but these days' entertainment and corporate tourists are also coming from these nations. Some big corporate houses are organizing business meetings, conferences, and other recreational activities here in Nepal from European countries. Trekking business has not limited to American and European young Indians also prefer to go for trekking to Pokhara and its surroundings.

Nepal's tourism situation has got significant changes in other aspects too. In the $70 \mathrm{~s}, 80 \mathrm{~s}$, and 90s there were special focuses on long-distance (the United States of America and Europe) tourists. At that time neither there was competition nor was the infrastructural development as now in the Nepalese tourism industry. At that time mostly adventure tourists used to come to see the Himalayas and natural beauty. They used to stay for a longer time especially in up higher Himalayan range. But for the last 10 years, their stayed period has become shorter because many facilities are built on the way of Himalaya. Road accessibility is the main reason for shortening the stay of the tour. Many jeeps and buses started to move over there where tourists used to walk. Entrepreneurs of Pokhara are not being able to bring tourists to the different probable places; there are many places where tourists may enjoy their trip. If the tourism sector of Pokhara would be able to convey the message of history and position that associated with different places may attract the interest of their guest. Like that, traditional herbal medicines can be a matter of interest to some tourists to visit Nepal (R4 and 5). They are lacking to identify the potentiality of such Himalayan herbal medicinal products and going through detailed investigation or exploration and promoting such new avenues of tourism to the target people. A number of people should involve the exploration, innovation, and marketing of such areas of the tourism industry. They may need to call for foreign experts too on appropriate management and up-gradation of the tourism business which can help for the exploration and up-gradation of tourism activities as a whole. Wilson et al., (2012) have mentioned that the competitiveness of a business is based on the unique market offering with customer-defined service quality. Managing the customer touch-point to provide an improved service experience 
has been understood for delivering customer-defined service quality. Continuous research and development activities are the basic foundations for making customers' defined service in a competitive market situation through different qualitative approaches like focus groups and interviews.

The majority of these days' tourists are born after 1990 who are also known as the millennium population. Their expectations are totally different from the previous groups which may compel the service providers more smart services. Service providers must be more tactful to those guests (R2, 4, and 5). It may not only the reasons for not having Nepal's own national flights across different parts of the world but also some services are not delivered as per the expectation of the visitors.

Holiday tourists are in the number one category, Europeans and other long-distance travelers still come to Nepal as a Himalayan destination. Nepal is recognized in the international market as a country of the Himalayas. They expect an authentic natural expedition from traveling Nepal. No one has found come to getting the experience of modern amenities in Nepal. Nepal lacks infrastructural development not only for tourism but also in every other aspect of modern life. Long-distance travelers want to compromise the facilities of modern days but demand a real and authentic experience of nature. Good road, wide modern airport, and other infrastructural facilities are at their home, they mentally prepared to compromise for those facilities while deciding to visit Nepal. Those understandings of visitors have helped Nepal to bring Nepalese tourism to date (R1, 3, 4, and 5). But realities have been changed these days. Long-distance tourists may compromise the modern facilities with the virgin authentic nature and may not get such a situation at some destinations.

\section{Change in Technology}

The visitor's trend is changing; the spending pattern is also changing. Demand is also changing. Technological change has also had a huge impact on tourism. It has made not only advanced but also highly demanding. The situation is being more challenging. One can get the entire world on his/her (hand) mobile phone (R1 and 7). As Li and Petrick (2008) have mentioned in their study of the marketing paradigm shift in the tourism of the $2021^{\text {st }}$ century. These days there are very little face to face interactions while previously it used to for hours. If the service provider is in direct contact with his/her guest, he/she can better understand the customer's expectation than being away. All the respondents have felt that the technological change has created a pressing need to them to change the total system of their business operation. 
It is constantly changing which has created problems in acquiring and training the required human resources. Most of the tourism service providers have felt that the reliable supply of internet facility. They have the experience of coming to a few visitors to do different project works. Such activities need speedy and reliable internet connectivity. Most of the visitors have chosen this destination as a peaceful and lonely destination. Some of the visitors want to talk from the tourist destinations to their friends and family while they have some amusing moment in their visit but they may not get reliable internet connectivity from places most of the places they visit especially in the trekking.

Chinese visitors have language problems which are coming in very increasing trend. The service providers have to talk with the group leader to serve them. These Chinese visitors extensively use mobile applications to ask for any service from the service providers and to get information about the destination. These kinds of work also demand very reliable internet connectivity in every step of visitors while they are in Nepal.

\section{Infrastructure and Connectivity}

The number one challenge is the infrastructure of Nepal not having innovation in this sector because these days' tourists expect every thinks from their visit they are not going to compromise anymore. The millennium populations seek adventure and luxury at the same time (R1, 3, 4, and 6). The next is international aviation connectivity. Nepal's flag carriers are in very limited numbers. It has to fully depend on the other nation's flights. Because of relatively expensive airfare, Nepal's probable visitors may alter their destination where they can get better airfare and connectivity. Not only Nepal has expensive international flights but also domestic flights are being expensive each year it has a ten percent growth in airfare last year only. In the study period tourists from third countries have fallen down, entrepreneurs themselves are not convinced about the fulfillment of the expectations of long-distance travelers from Europe and the United States of America (USA). It may not only the reasons for not having Nepal's own national flights across different parts of the world but also some services are not delivered as per the expectation of the visitors.

\section{Major Market Shift}

These days the major markets are India and China while India is keeping the position from the very beginning and China coming ahead from the last decade (almost all respondents). Both countries cover a significant portion of total visitor arrivals. The others are the USA, United Kingdom (UK), and Sri Lanka respectively. These five are major countries 
for the Nepalese tourism business. The majority of visitors are holiday followed by religion and adventure (Ministry of Culture, Tourism Civil Aviation, 2018). While in previous days' majority of visitors use to from USA and Europe focusing on adventure activities.

After the conflict and the royal massacre, Nepal has no more Japanese tourists. The number of tourists from Hong Kong, Singapore, and Japan decreased, and Korean and Chinese are in increasing numbers. Chinese tourists are an increasing trend after 2005. As the nationalities of visitors have changed the expectation has also changed and the categories of Indian visitors also changed. Indians visitors are in three categories holiday/ pleasure, pilgrimage, and educational tour respectively. The pilgrimage tourists come both for Muktinath and/or Pashupatinath and some time for Kailash Mountain. The Kailash trip is still cheaper if they go from Nepal so they prefer to take the Nepal route to go to Kailash Mountain too (R3, 4, 5and 6). Nepal's good signal is that once visit and coming repeatedly especially in Pokhara that is about 40 percent of visitors is re-visitors.

\section{Human Resources}

Tourism entrepreneurs of Pokhara themselves accept that they lack skilled human resources to provide stipulated services. It is not an international standard because of trained human resources. They are not being able to develop and hold skilled human resources in the tourism industry. "I am running my own business for the last fifteen years; I am also not being to hold skilled humans" $(\mathrm{R}, 4)$. It is being a training center. If anyone gets to experience and skill in this tourism and hospitality sector, leave the firm for going abroad. This is a very common phenomenon in this industry.

Hospitality is also a coordinated work (Binkhorst \& Den Dekker, 2009) if all workers do fine and one will unable to do accordingly all will fail, which means the system or whole trip of that group fails and become a matter of negative word of mouth. To provide quality service providers must have quality human resources and good (quality) remuneration to the service employees. Most of the respondents are agree with not having a reasonable salary and payment system for those working here in this industry. Unless the internal customers (employees) will not get fully satisfied how can they expect external customers' satisfaction (Bitner et al., 1990). Above all, Nepalese tourism service providers welcome their guests with their very inner hearts. As Nepalese tradition tells those guests is God (atithi debo bhawa!) you must treat your guest as you treat your God. 


\section{Change in Competition}

There is unhealthy competition in the tourism services and also price undercutting to get guests. Respondent six share his view that trekking sector income downfall in the year 2018 instead of an increasing number of tourists by more than ten percent which may be the effect of price undercutting. Entrepreneurs cut-price of services to get more guests and total income decreased. Many foreigners do not know about Nepal but if one asks to know about Mount Everest most of them say yes. So, it should be promoted as the nation of Mount Everest except for India and China.

All respondent entrepreneurs are unanimously pointing out the competitive situation of the Nepalese tourism market. New service providers are entering with lower service prices and lower service quality. Lowering the price mean compromising the service delivery which ultimately leads to a bad experience for the visitors. This rivalry situation has promoted a negative image of destination Nepal, especially western countries. Di Dominico and Miller (2017) mentioned that maintaining ethics in tourism entrepreneurship is a challenging task of the contemporary tourism industry.

\section{Degradation of Nature}

Significant numbers of visitors come to Nepal as a virgin destination and natural beauty. Most of the long-distance travelers who stay a longer duration come for mountain claiming and adventurous tourism but most of the places are degraded in the name of infrastructure development. Those places visitors used to walk calm and freeway but today different polluting devises are in the operation to build the road and other such infrastructures. These places must be kept virgin to attract such group of visitors. Like that other natural resources preservation activities should take place.

\section{Tailoring the Services}

Communication is another challenge especially for Chinese visitors to understand the expected services. Because of the communication problems with Chinese visitors, service providers have to fully rely upon the Chinese tour organizer. All the Chinese visitors are taught about Nepalese tourism activities before departing from home. The understanding of Nepal is started from their home which they may carry back with them without knowing the truth about the destination; he/she may have given misleading information too by the initial information providers (R1 and3). Because of the language barrier, Chinese visitors are not getting the full experience of the visit. Though, these days they can communicate with the help of mobile 
applications and computer programs which may not able to match with a sense of harmony and the real message of the event.

Furthermore, tailoring the services as per the guest is provoked confusion in the service provider. Even Indian nationality has different service demands. One cannot generalize Indians demand this set or package of service. The first category is from the south and southwest India who would like to visit Muktinath or such religious places also demand different packages of service. Some of them are purely religious groups they do not concern other matters while few of them demand other services too. The next is the middle class who have some savings for entertainment and outgoing objective. It is in big volume mostly from Uttar Pradesh, Bihar, or close bordering states (R1, 4, and 5). In this group, there is a mix-up of three-generation grandfather, son, and grandson. Their main objective is entertainment but differently.

\section{CONCLUSIONS}

There is a huge change in expectation and visitor's type, in the previous day most of the visitors used to come for trekking and mountain climbing but these days conference and corporate visitors are also coming. These diverse groups definitely demand different tastes and flavors. In the 80 s government and other private sector tourism workers used to focus on the long-distance traveler while the short distance travelers from neighboring nations were not considerations. The probability of visiting proximate distance is much higher than the longer distance. Today's visitors are more demanding from the tourism service providers, they demand luxury and adventure at the same time entrepreneurs are compelled to manage it accordingly.

Technology has an enormous influence on tourism, particularly visitors' expectations and service delivery. On one hand, it has provided facilities in this industry on the other hand it has minimized the physical encounter and interaction between service providers and service receivers. Indirect interaction between service providers and service receivers may not be appropriate in all situations when the service provider's understanding of service needs and the customer's understanding of service need may differ there may be a mismatch of service expectation and performance that lead to dissatisfaction and grumble to service providers. No visitors decide if he/she cannot travel to the destination pleasantly so road and air travel must be smooth and have better air connectivity on reaching the destination without any problem. Air, as well as road connectivity, is poor which may create problems for higher numbers of visitors without advancing such infrastructures in the major destination. The quality assuring 
system with a defined standard of the benchmark is needed in every aspect of tourism demand for its smooth advancement.

The tourism market has shifted from adventure to meeting, incentive, conference and exhibition (MICE), and pilgrimage and long trekking and adventure to short entertaining adventure activities. Without trained and experienced hands Nepalese tourism industry cannot move ahead. Strategies must be adapted to retain and upgrade the tourism service providers for their sustainability. To ensure stipulated service quality a healthy competition is desirable among the different avenues of tourism services by keeping the nature for the upcoming generation too.

\section{REFERENCES}

Alina, B., \& Daniel, B. (2014). Is there evidence of a European lifestyle entrepreneur in tourism? The Annals of the University of Oradea, 229.

Bakas, F. E., Duxbury, N., \& de Castro, T. V. (2019). Creative tourism: Catalyzing artisan entrepreneur networks in rural Portugal. International Journal of Entrepreneurial Behavior \& Research.

Binkhorst, E., \& Den Dekker, T. (2009). Agenda for co-creation tourism experience research. Journal of Hospitality Marketing \& Management, 18 (2-3), 311-327.

Bista, R. (2009). Tourism policy, possibilities, and destination service quality management in Nepal.

Bitner, M. J., Booms, B. H., \& Tetreault, M. S. (1990). The service encounter: Diagnosing favorable and unfavorable incidents. Journal of Marketing, 54 (1), 71-84.

Blodgett, J., Bakir, A., \& Hill, D. (2009). Complaining behavior: Cross-cultural or situational? An exploratory study of the Indian nationals living in the United States. ACR AsiaPacific Advances.

Buhalis, D., \& Deimezi, O. (2004). E-tourism developments in Greece: Information communication technologies adoption for the strategic management of the Greek tourism industry. Tourism and Hospitality Research, 5 (2), 103-130.

Castro, C., \& Ferreira, F. A. (2019). Entrepreneurs' self-perception of skills in rural tourism. European Journal of Tourism Research, 21, 50-68

Chan, G. S. H., Hsiao, A. C. H., \& Lee, A. L. Y. (2016). Exploration of customer compliant behavior toward Asian full-service restaurants. International Journal of Marketing Studies, 8 (2), 46. 
Charmaz, K. (2008). Grounded theory as an emergent method. Handbook of Emergent Methods, 155-172. Academic Publishers.

Creswell, J. W., Plano Clark, V. L., Gutmann, M. L., \& Hanson, W. E. (2003). Advanced mixed methods research designs. Handbook of mixed methods in social and behavioral research, 209-240. Springer.

Glaser, B. G., \& Strauss, A. L. (2009). The discovery of grounded theory: Strategies for qualitative research. Transaction Publishers.

Granot, E., Brashear, T. G., \& Motta, P.C. (2012). A structural guide to in-depth interviewing in business and industrial marketing research. Journal of Business \& Industrial Marketing, 27 (7), 547-553. doi:10.1108/ 08858621211257310

Gretzel, U., Fesenmaier, D. R., Formica, S., \& O’Leary, J. T. (2006). Searching for the future: challenges faced by destination marketing organizations. Journal of Travel Research, 45 (2), 116-126.

Jaafar, M., Abdul-Aziz, A. R., Maideen, S. A., \& Mohd, S. Z. (2011). Entrepreneurship in the tourism industry: Issues in developing countries. International Journal of Hospitality Management, 30 (4), 827-835.

Khanal, B. P. (2020). Impact of the COVID-19 in tourism industry in Nepal and policy recommendation. Journal of Tourism \& Adventure, 3 (1), 76-91.

Lin, Y. C., Lin, M. L., \& Chen, Y. C. (2017). How tour guides' professional competencies influence on service quality of tour guiding and tourist satisfaction: An exploratory research. International Journal of Human Resource Studies, 7 (1), 1-19.

Li, X., \& Petrick, J. F. (2008). Tourism marketing in an era of paradigm shift. Journal of travel research, 46 (3), 235-244.

Lu, J., \& Nepal, S. K. (2009). Sustainable tourism research: An analysis of papers published in the Journal of Sustainable Tourism. Journal of Sustainable Tourism, 17 (1), 5-16.

Marshall, C., \& Rossman, G. B. (1999). The "what" of the study: Building the conceptual framework. Designing qualitative research, 3, 21-54.

McCollough, M. A., Berry, L. L., \& Yadav, M. S. (2000). An empirical investigation of customer satisfaction after service failure and recovery. Journal of Service Research, 3 (2), 121-137.

Ministry of Culture, Tourism and Civil Aviation. (2018). Nepal tourism statistics 2019. Government of Nepal.

Mura, P., \& Khoo-Lattimore, C. (Eds.). (2018). Asian qualitative research in tourism: 
Ontologies, epistemologies, methodologies, and methods. Springer.

Novelli, M., Morgan, N., \& Nibigira, C. (2012). Tourism in a post-conflict situation of fragility. Annals of Tourism Research, 39 (3), 1446-1469.

Page, S.J., (2019). Tourism Management $6^{\text {th }}$ Edition. Routledge.

Pandey, R. N., Chettri, P., Kunwar, R. R., \& Ghimire, G. (1995). A case study on the effects of tourism on culture and the environment. UNESCO Principal Regional Office for Asia and the Pacific.

Phelan, C., \& Sharpley, R. (2012). Exploring entrepreneurial skills and competencies in farm tourism. Local Economy, 27 (2), 103-118.

Power, S., Di Domenico, M., \& Miller, G. (2017). The nature of ethical entrepreneurship in tourism. Annals of Tourism Research, 65, 36-48.

Selby, A., Petäjistö, L., \&Huhtala, M. (2011). The realization of tourism business opportunities adjacent to three national parks in southern Finland: entrepreneurs and local decisionmakers matter. Forest Policy and Economics, 13 (6), 446-455.

Sharma, P. (2012). Tourism in Nepal 2030. Nepal, 2030, 73-92.

Shaw, G. (2014). Entrepreneurial cultures and small business enterprises in tourism. The Wiley Blackwell companion to tourism, 120-131.

Tribe, J. (2006). The truth about tourism. Annals of Tourism Research, 33 (2), 360-381.

Tribe, J., Xiao, H., \& Chambers, D. (2012). The reflexive journal: Inside the black box.

Wilson, A., Zeithaml, V., Bitner, M. J., \& Gremler, D. (2012). Services marketing: Integrating customer focus across the firm (No. 3rd Eu). McGraw Hill.

ZeithamlV.A., Bitner M.J. \&Gremler D.D. (2006), Services marketing- integrating customer focus across the firm. $7^{\text {th }}$ Edition. McGraw-Hill Education.

Zhang, J. (2018). How could we be non-western? Some ontological and epistemological ponderings on Chinese tourism research. Asian qualitative research in tourism: Ontologies, epistemologies, methodologies, and methods, 117-136. 